\title{
Brittle structures focused on subtle crustal heterogeneities: implications for flow in fractured rocks
}

3

4

\section{A. M. Soden ${ }^{1,2}$, Z. K. Shipton ${ }^{1}$, R.J. Lunn ${ }^{1}$, S. I. Pytharouli ${ }^{1}$, J. D. Kirkpatrick ${ }^{3}$,A. F. do}

Nascimento $^{3}$ and F. H. R, Bezerra ${ }^{4}$

${ }^{1}$ University of Strathclyde, UK, ${ }^{2}$ now at University College, Dublin, Ireland, ${ }^{3}$ Colorado State University, USA. ${ }^{4}$, Universidade Federal do Rio Grande do Norte, Brazil.

\begin{abstract}
Host rock mechanical heterogeneities influence the spatial distribution of deformation structures and hence, predictions of fault architecture and fluid flow. A critical factor, commonly overlooked, is how rock mechanical properties can vary over time, and how this will alter deformation processes and resultant structures. We present field data from an area in the Borborema Province, NE Brazil, that demonstrate how temporal changes in deformation conditions, and consequently processes, exerts a primary control on the spatial distribution and geometric attributes of evolving deformation structures. Further, each temporal deformation phase imparted different hydraulic architecture. The earliest flowing structures localized upon subtle ductile heterogeneities. Following fault formation, both fault core and damage zone were flow conduits. In later stages of faulting pseudotachylyte welding created a low-permeability fault core and annealed high-permeability fractures within the fault damage zone. Modern flow occurs along a zone of later open shear fractures, defined by the mechanical strength contrast between the host rock and annealed fault. This second hydraulicallyconductive zone extends 100 s of meters from the edge of the annealed fault damage zone, creating a flow zone far wider than would be predicted using traditional fault scaling relationships. Our results demonstrate the importance of understanding successive deformation events for predicting the temporal and spatial evolution of hydraulically active fractures.
\end{abstract}




\section{Introduction}

Geometrical attributes of faults and fractures (length, orientation and spatial distribution) are of primary importance in predicting fluid flow through fracture networks. For any particular fracture system these attributes are controlled by rock mechanical properties and in-situ stress at the time of fracture formation. Rock mechanical properties are dependent on the physical conditions (e.g. pressure, temperature, pore fluid) at the time of deformation. Changes in rock mechanical properties can alter deformation processes, and hence deformation structures, during successive phases of deformation. In turn, subsequent deformation phases can reactivate or overprint structures, modifying their mechanical properties. Therefore, fracture networks are not purely stochastic in nature, and the ability to simulate realistic fracture systems depends on coupling accurate statistical quantification of fracture attributes with an understanding of the evolution of the deformation processes, and the attendant structures formed prior to and during fracture formation. This is particularly pertinent to fracture systems in basement terrains that have experienced multiple deformation events. Accurate characterization of fracture population attributes in crystalline rock at both seismic and sub-seismic resolution is increasingly important as crystalline rocks are targets for nuclear waste repositories (Degnan et al., 2003), enhanced geothermal systems (e.g. Sausse et al., 2006) and hydrocarbon exploration (e.g. Koning, 2003; Schutter, 2003; Slightam, 2012). Furthermore, containment periods for $\mathrm{CO}_{2}$ sequestration and nuclear waste storage are so long (between $10^{3}$ and $10^{6}$ years) that predictions of temporally varying rock hydraulic properties (e.g. due to glacial advance and retreat) are required as input to the safety cases for potential storage/repository sites.

A critical factor, commonly overlooked, is how host rock mechanical properties can vary over time, and how this will alter deformation processes and influence the type, and geometrical attributes of, resultant deformation structures. For example in sandstones, as mechanical strength increases due to diagenesis, the failure mechanism can change from cataclasis (forming deformation bands) to fracturing (forming joints) (Johansen et al., 2005; Davatzes et al., 2005). Similarly, fracture attributes such as spacing and length, are the product of the host rock mechanical properties at the time of formation (Cooke et al., 2006; Moir et al., 2010), which may differ from present-day mechanical properties (Shackleton et al., 2005; Laubach et al., 2009). The impact of diagenetic or depositional processes on host rock properties is evident in along fault variations in fault zone architecture (e.g. Eichhubl et al., 2009; Soden and Shipton, 2013). Thus predictions of fracture and fault zone architecture should consider previous mechanical states and not merely the present mechanical state, particularly in areas that have a complex tectonic history. 
Furthermore, it is widely recognized that host rock mechanical heterogeneity can influence the spatial distribution of initial deformation structures (Crider and Peacock, 1996; Fischer and Polansky, 2005), and hence, any resulting fault architecture (Childs et al., 2009). Contrasts in mechanical strength localize stress (Pollard and Aydin, 1988; Moir et al., 2013) and act as sites for fracture initiation (McConaughy and Engelder 2001; d'Alessio and Martel, 2005) or termination (Cooke et al., 2006). What has not been fully explored is the impact of the mechanical heterogeneity created by deformation structures formed under deformation conditions that vary over geologic time, on subsequent fracture development.

In this study we present data from the Jucurutu fault located in Jucurutu county in the state of Rio Grande do Norte, NE Brazil. The fault cuts crystalline basement rocks and was initially documented by Kirkpatrick et al., (2013) as part of an investigation of regional fault systems. We have carried out a detailed examination of the structures exposed within a $0.09 \mathrm{~km}^{2}$ area adjacent to and including the Jucurutu fault, recording structures from the centimeter to 100's of meters scale. Our data indicate how changes in deformation conditions, and consequently processes, control the observed pattern of deformation structures. We show that in each deformation phase, both the spatial distribution and geometric attributes of the evolving structures are governed by the locations of the structures formed in previous phases. We propose that existing structures act as mechanical heterogeneities, resulting in high stress concentrations that lead to fracture nucleation. This results in discrete temporal episodes of differing, yet related, patterns of hydraulically conductive structures.

\section{Geological Setting}

Our study examines ductile and brittle deformation structures in Neoproterozoic gneisses of the Borborema Province, NE Brazil (Fig.1). Regionally the Archean to Proterozoic basement is cut by a system of steeply-dipping, E-W and NE-SW trending, dextral strike-slip shear zones intruded by Neoproterozic granites (Vauchez et al., 1995; Arthaud et al., 2008). The shear zones developed during the Brasiliano Orogeny ( 750-540Ma), and are defined by steeply dipping mylonitic belts hundreds of kilometers long and tens of kilometers wide (Brito Neves et al., 2000).

Continental break-up during the Cretaceous generated the Potiguar Basin in the north of the Borborema Province as part of a system of failed rifts. The study area lies on the border of such a rift, the Cariri-Potiguar trend that extends southwest from the edge of the Potiguar Basin (Fig. 1) (Matos, 1992). Faults bounding the Potiguar basin have throws up to $5 \mathrm{~km}$ and are observed on seismic sections to offset the crystalline basement (De Castro et al., 2012). On a regional scale the rift faults coincide with the basement mylonitic fabric (Matos, 1992; De Castro et al., 2008; 
Kirkpatrick et al., 2013). Substantial uplift and erosion of the region during the Cenozoic has exposed the basin margins and deeper parts of the rift systems. Exhumation is interpreted to have occurred at $\sim 90-100 \mathrm{Ma}$ and again post-20Ma. The former event corresponds to rifting and cooling to temperatures less than $100^{\circ} \mathrm{C}$ and the latter to cooling from around $60^{\circ} \mathrm{C}$. Together these are thought to represent $\sim 3 \mathrm{~km}$ of denudation (Nóbrega et al., 2005; Morais-Neto et al., 2009).

Our study site is located south of the Potiguar basin within the Piranhas shear zone, a 100km-scale shear zone that locally trends NE swinging to a ENE trend further south. We focus on a section of a brittle fault, the Jucurutu fault (JF), which cuts a strongly mylonitised section of the Piranhas shear zone (Fig. 1).

The Jucurutu fault is one of three NE-SW trending brittle faults that make up the Rio Piranhas fault system. The fault system extends $\sim 150 \mathrm{~km}$ along strike, from the Açu reservoir in the north to the Rio do Peixe basin in the south. The only observed offset indicator is a displaced granite pluton boundary on the São Rafael fault, with an apparent dextral offset of the order of $\sim 150 \mathrm{~m}$. No piercing point data exist for these faults, so the dip-slip component of the total slip is unknown. However observations of slickenlines and corrugations on subsidiary faults indicate net oblique dipslip offsets (Kirkpatrick et al., 2013). Based on interpretation of Landsat images, the Jucurutu fault (JF) has a trace length of $40 \mathrm{~km}$ and a regional trend $053^{\circ}$. At the regional scale the JF runs parallel to the shear zone, although locally the fault cuts the mylonite foliation at a low angle. Kirkpatrick et al. (2013) showed that on the basin scale, the geometry of the Jucurutu fault, and other faults of a similar age, is strongly controlled by the pre-existing Brasiliano ductile fabric. However at the outcrop scale, the mylonitic foliations have only a weak influence on the architecture of the Jucurutu fault zone.

Reservoir-induced microseismic events associated with the São Rafael fault, the northernmost fault in the Rio Piranhas system, also suggest that the spatial distribution of brittle structures are not solely dictated by the pre-existing ductile fabric. Earthquake hypocenters delineate a cloud of microseismicity $2 \mathrm{~km}$ long, $230 \mathrm{~m}$ to $400 \mathrm{~m}$ wide and at depths of $1.5-2 \mathrm{~km}$ that coincides with the São Rafael fault, which itself is sub-parallel to the regional foliation. Pytharouli et al., (2011) demonstrated that the microseismicity occurs on multiple fractures some of which are clearly orientated at high angles to the fault and mylonite foliation, the remainder are sub-parallel to both fault and host rock fabric. In this study we observe laterally extensive, open fractures at high angles to the Jucurutu fault, which we propose are analogous to those hosting the modern-day seismicity recorded at Sao Rafael. 


\section{Field Data}

130 The study area at Jucurutu is excellently exposed in the bed of the Piranhas River (Fig. 2). The river

131 inundates the area during the rainy season but for the remainder of the year is confined to two

132 channels approximately $10 \mathrm{~m}$ wide either side of an 'island' with $\sim 80 \%$ outcrop exposure (Fig.

133 2b).The exposure comprises ridges of intact, smooth crystalline rock which have been highly

134 polished by the river flow, making sample collection difficult. Mapping at meter scale was carried

135 out using line transects, circular scanlines, base-line mapping and at 100 meter scale from low-

136 altitude aerial photos (Fig. 2). At the field site, the southerly strand of the Piranhas River runs along

137 the trace of the Jucurutu fault. In one location (around x_x' on Fig. 2), the channel takes a jog to the

138 east, exposing the fault core; elsewhere the central fault core is covered by the channel even in the

139 lowest flow conditions.

140 At the study site the host rock is a low-grade, quartz-feldspar-epidote gneiss that is strongly

141 mylonitized, with a prominent sub-vertical foliation trending $\sim 034^{\circ}$ (Fig. 2c \& 2d). The foliation is

142 defined by compositional banding and by aligned chlorites and muscovites (Kirkpatrick et al.,

143 2013). Kinks in the foliation trend define centimeter-wide to tens of centimeter-wide ductile shear

144 zones oriented sub-perpendicular to mylonite foliation. These small shear zones represent strain

145 localization after the formation of the main foliation. Additionally, a section of the foliation close to

146 the river is rotated towards a trend of $050^{\circ}$ (Fig. 2a \& 2d) suggesting folding of the foliation on the

147 tens of meters scale within the mylonitized zone.

148 Brittle structures are observed in the study area across a range of length scales from tens of 149 centimeters long fractures to the $40 \mathrm{~km}$ long Jucurutu fault (JF). Based on mineral fill and cross-

150 cutting relationships of the brittle structures we suggest three phases of brittle deformation can be

151 distinguished, which were active under different deformation conditions. The first phase is

152 associated with epidote bearing fluids, the second occurred at mid-crustal levels under high-stress

153 conditions, and the final phase at shallow levels and in the absence of mineralizing fluids. We

154 present the observations of each fracture generation in the order in which they formed and suggest

155 the deformation condition parameters indicated by the recorded data.

156 Epidote mineralization is observed in fractures ranging from tens of centimeters long to tens of 157 meters long, in single fractures (Fig. 3a \& c) and in en echelon fracture arrays (Fig. 3b). The 158 shortest epidote-filled fractures are found adjacent to the Jucurutu fault core (Fig. 2: LT1-LT5).

159 These fractures are tens of centimeters long, millimeters wide, and form a closely spaced, irregular

160 fracture network (Fig. 3a). Although they have a range of orientations from $000^{\circ}$ to $170^{\circ}$ (Fig. 4a)

161 the fractures dominantly strike at high angles to the foliation and the JF. The short epidote-filled 
162 fractures are largely restricted to the area adjacent to the JF fault core outcrop and are not as 163 prevalent moving along fault strike to the SE. Rather, epidote-filled shear-fractures tens of meters 164 long and 2-10 centimeters wide are observed along fault strike to the SW and up to $150 \mathrm{~m}$ 165 perpendicular to the Jucurutu fault (Fig. 2a \& Fig. 3b \& c). Epidote-filled shear fractures adjacent to the JF cross-cut foliation at a low angle $\left(5^{\circ}\right.$ and $\left.30^{\circ}\right)$ and are sub-parallel to the JF trend, those further from the JF are sub-perpendicular to both the foliation and the fault. The maximum length a single epidote-filled shear-fracture was traced for was $42 \mathrm{~m}$, the minimum length was $5 \mathrm{~m}$, but the terminations of the shear-fractures were not observed due to the limited extent of exposures.

The majority of the tens-of-meter long epidote shear fractures observed display a sinistral shear sense and are associated with localized rotation of the mylonite foliation over centimeters to meter wide zones surrounding the shear fracture (Fig. 3 b, d \& e). Four of the epidote-filled fractures (Fig. 2a) are associated with sinistrally offset granite dykes, with apparent horizontal separation of between $3 \mathrm{~m}$ and $9 \mathrm{~m}$. In one instance a section of dyke and gneiss foliation adjacent to the epidotefilled fracture is rotated with a sinistral shear sense; seemingly sheared along the epidote-filled fracture (Fig. 3e). A meshwork of fine epidote veins extends from the epidote-filled fracture into both the gneissic host rock and sheared dyke in a geometry consistent with sinistral slip (Fig. 3f).

178 The dyke may have been sheared by either the ductile shear on which the later brittle fault 179 developed or by the epidote-filled shear-fracture under semi-brittle conditions. Two generations of 180 highly indurated gouge can be identified in the epidote shear fractures adjacent to the JF (Fig. 3d). 181 The first generation is composed of millimeter-sized angular to rounded mylonite clasts in an 182 epidote-quartz matrix, the second generation is composed of a fine-grained red gouge tightly 183 cementing clasts of epidote from the first generation gouge.

184 Epidote fractures and en echelon arrays one to two meters long are found at a distance of $150 \mathrm{~m}$ 185 from the river (Fig. 2a: FD2 \& FD3 \& Fig 3b \& c). Centimeter-wide ductile shear zones are cut by 186 single epidote-filled fractures that are oriented parallel to the zone of sheared foliation, and by enechelon epidote vein arrays. The overall en-echelon array trend parallels the ductile shear zone with individual veins cross-cutting the shear zone at a high angle (Fig. 3a, b \& c). Furthermore, in each observed case the en-echelon array and ductile shear have the same shear sense.

190 Epidote mineralisation is interpreted as indicating temperatures of $\sim 200^{\circ}-300^{\circ} \mathrm{C}$ (Gulibert and Park, 191 1986; Bruhn et al., 1994). Assuming a geothermal gradient of $20^{\circ}-30^{\circ} \mathrm{C} / \mathrm{km}$ (cf. Lisker, 2004) the 192 abundance and spatial extent of epidote mineralized shear fractures, as well as evidence of 193 cataclasite reworking (Fig. 3d) indicates a significant phase of deformation and associated fluid 194 flow at depths between $7 \mathrm{~km}$ and $15 \mathrm{~km}$. 
195

196

197

198

199

200

201

202

203

204

205

206

207

208

209

210

211

212

213

214

215

216

217

218

219

220

221

222

223

224

225

226

227

228

The second generation of brittle structures is the Jucurutu fault itself (Fig. 5) and a set of annealed, unmineralised, fractures that occur in the adjacent rock (Fig. 6a \& b). Here we define annealed as meaning that fractures do not split when hit with a hammer, thus are not planes of weakness. We infer that these fractures are closed tight or sealed and are therefore incapable of transmitting fluid in the present day. Fracture aperture is $<0.1 \mathrm{~mm}$ (indistinguishable with the naked eye) making it impossible to identify in the field if the fractures are mineralized. It was not possible to sample the annealed fractures for thin section analysis due to the highly river polished exposure, which made any form of hand sampling away from open joints (where a chisel could be inserted) extremely difficult. Due to the remote location we did not have access to a rock drill. The annealed unmineralised fractures are consistently associated with pseudotachylyte veins that extend from the Jucurutu fault and cross-cut the annealed fractures, indicating the annealed fractures formed at similar high temperatures and pressures. Although we cannot confirm the actual fracture sealing mechanism we suggest potential mechanisms in our discussion. This does not detract from our main hypothesis, however, since it is not the absolute values of the mechanical properties that affect the localization of future structures but the presence of mechanical heterogeneities with discrete boundaries that act to focus fracture nucleation (Moir et al., 2013).

At the study location we define the JF fault core as the $1.4 \mathrm{~m}$ to $2.6 \mathrm{~m}$ wide zone of highly indurated, chaotic breccias, bound by two sub-vertical planar fault walls dipping $\sim 80^{\circ}$ (Fig. $5 \mathrm{a} \& \mathrm{~b}$ ). The breccias are composed of randomly oriented angular clasts, millimeters to 50 centimeters in diameter, strongly cemented in a fine-grained purple-grey matrix. No offset markers could be identified along the JF but breccia strands up to $15 \mathrm{~m}$ long branching from the fault, orientated $\sim 25$ $30^{0}$ counterclockwise to the fault wall are consistent with sinistral slip (Kirkpatrick et al., 2013). Clasts containing fine epidote veins are found in the breccia (Fig. 5c) but no epidote veins are observed to cut the breccia matrix. The matrix itself is composed of epidote and chlorite grains strongly cemented with an aphanitic purple-grey crystalline material. The same aphanitic material fills fractures cross-cutting the breccia clasts and matrix, as well as fractures extending from the core into the host rock immediately adjacent to the core. These fractures have chaotic, cross-cutting orientations and geometries. Differential erosion of the fault breccia has created an irregular surface from which it is possible to sample the clasts, matrix and cross-cutting fractures. Microscopic observations of the aphanitic material from the fault core show it to have characteristics consistent with pseudotachylyte (Kirkpatrick et al., 2013). The presence of pseudotachylyte indicates slip at mid-crustal depth as high normal stress promotes frictional melting (Sibson and Toy, 2006). The volume of pseudotachylyte and the multiple cross-cutting strands suggest several melt-generating events. The persistence of pseudotachylyte throughout the JF has created a highly indurated fault 
core; induration and healing of cataclasites by pseudotachylyte is a phenomenon recognized in both field and laboratory settings (Di Toro and Pennacchioni, 2005; Griffith et al., 2012)

The host rock surrounding the JF is intensely fractured by a high-density, irregular network of closely spaced $(<10 \mathrm{~cm})$, tens of centimeter-long, unmineralised, annealed fractures (Fig. $6 \mathrm{a} \& \mathrm{~b}$ ). These fractures cross-cut each other and the tens of centimeter-long epidote-filled fractures adjacent to the JF fault core. The annealed fractures are in turn cross-cut by pseudotachylyte strands extending from the fault core. Annealed fractures have a range of orientations between 000 and 180, though overall fracture strike is at high angles to the foliation and to the Jucurutu fault (Fig. 6c). Both dextral and sinistral shear sense indicators were recorded (Fig. 6d) and in places conjugate fractures have developed. Annealed fractures were observed along the length of the JF (sampled in FD5, $6 \&$ 7) including surrounding the epidote-filled shear fractures along-strike to the SE of JF fault core exposure (Fig. 2a). No evidence of previous mineralization was observed in any of the annealed fractures.

The intensity of fracturing in the host rock along JF strike was measured using circular scanlines along five line transects perpendicular to the fault core (Fig. 2a). On each line transect circles $1 \mathrm{~m}$ in diameter were spaced at 4 to $8 \mathrm{~m}$ intervals, depending on exposure. Background joint density was measured using circular scanlines at locations $210 \mathrm{~m}$ and $160 \mathrm{~m}$ from the JF, on the west and east bank respectively. All visible fractures intersecting the circle were counted, with no differentiation made between epidote-mineralized and unmineralised, annealed fractures. As fractures intersecting the circle were counted rather than fractures terminating within the circle, the measure obtained is for fracture intensity rather than fracture density (Mauldon et al., 2001). On the west bank background fracture intensity is 10 fractures $/ \mathrm{m}$ and on the east bank 16.5 fractures $/ \mathrm{m}$ Fracture intensity decreases outwards from the fault core, from a maximum of 58 fracture/m reaching background levels between $40 \mathrm{~m}$ and $60 \mathrm{~m}$ from the fault wall (Fig. 8). The spatial distribution of fractures in a zone of high-intensity, chaotic fracturing surrounding the JF defines the JF damage zone, which we interpret to have formed during slip on the JF. Damage zone width and fracture intensity is heterogeneous along fault strike. On average fracture intensity along WT4 is twice background levels, while WT2 records fracturing almost three times background value.

The third and final generation of deformation structures are open shear fractures (Fig. 8a) and open fracture zones meters to tens of meters long, (observed in well exposed areas FD1-4 and FD8; Fig. 2). Open fractures have apertures $\geq 1 \mathrm{~mm}$ and no mineral fill or staining (Fig $8 \mathrm{~b} \& \mathrm{c}$ ). Occurring outside the JF DZ, their geometric properties are in contrast to the dense, cross-cutting, annealed fracture network and short epidote-mineralized fractures observed in the JF damage zone. Open 
262 fractures and fracture zones are more widely spaced (Fig. 8a), orientated sub-parallel to each other 263 and at a constant high angle to foliation (Fig. 9). All observed open fractures have near-vertical

264 dips. At least three isolated open fracture zones were observed in the JF damage zone, but in 265 general where the annealed meshwork fractures are present adjacent to the JF the open fractures are 266 absent (Fig. 7a). No open fractures or fracture zones were observed cutting the JF fault core. Three 267 of the open fracture zones were traced over 100 meters from the edge of the annealed JF damage 268 zone (Fig. 2 WT and ET transects) a further eighteen open fractures were traceable for between 10 269 and 20 meters. However, due to sand cover the terminations of neither individual open fractures nor 270 fracture zones were observed.

271 Open shear fractures and en echelon fracture arrays crosscut centimeter-scale epidote veins (Fig. 272 10a), ductile shear zones (Fig. 10a) and nucleated at the edges of epidote-filled shear fractures 273 (Fig.8d \& 10b). The open en echelon arrays share the same trend as the ductile shear zones and 274 epidote veins, those open fractures nucleating at the edges of epidote-filled shear fractures form at a 275 high angle to the shear-fracture. Both apparent dextral and sinistral shear sense indicators are 276 observed (Fig. 9b) consistent with normal reactivation, whereby only a minor reorientation of the stress field will result in a change in the apparent slip direction in the horizontal exposure.

\section{Structural and Hydraulic Evolution}

279 Based on the field data we have developed a conceptual model for the structural and hydraulic 280 evolution of the fault and fracture system at Jucurutu (Fig. 11). The crystalline basement has experienced multiple deformation phases under deformation conditions that evolved through time.

282 The deformation structures observed at the study site are consistent with deformation occurring 283 under progressively decreasing temperatures (Fig. 12). Initial deformation was ductile and occurred 284 at greenschist facies conditions during the Brasiliano orogeny. Subsequently brittle deformation was associated with epidote mineralisation and pseudotachylyte formation as the area experienced rift related extension and exhumation during the Cretaceous (Kirkpatrick et al., 2013). Although the exact timing of open fracture formation is unclear in the absence of mineralizing fluids, the crosscutting relationships and trends of the open fractures show that they formed later than the JF damage zone, presumably at lower stresses during Cenozoic exhumation. As deformation conditions changed so too did the deformation processes and consequently the type of structure formed. Each generation of structure created a discrete mechanical heterogeneity within the host rock that acts as a nucleation site for later structures; rather than structures exploiting the mechanical anisotropy of the mylonitic fabric (Shea \& Kroneberg, 1993; Tien et al., 2006). This observation of fracture nucleation on discrete mechanical boundaries is in keeping with the 
numerical modelling results of Moir et al., (2013). Our observations support a conceptual model with four distinct phases of deformation, each later phase being affected by the presence of prior deformation structures

The initial phase of deformation during the Brasiliano orogeny formed the regional Piranhas Shear zone. Observations of synkinematic growth of chlorite and muscovite, and crystal-plastic deformation of quartz and plagioclase, indicates mid-crustal, greenschist-facies conditions and temperatures of up to $\sim 450^{\circ}$ (Kirkpatrick et al., 2013). Within the mylonitsed zone, further localization of strain formed broad tens of meter-scale folds, as suggested by the foliation rotation from $30^{\circ}$ to $50^{\circ}$ adjacent to the JF, down to centimeter-wide ductile shear zones (Fig. 11a).

Epidote bearing structures at the centimeter- and meter-scale are localized on ductile shear zones, indicating that the ductile shear zones acted as mechanical heterogeneities on which the fractures initiated (Fig. 11b). The epidote-filled structures are themselves crosscut by unmineralized, annealed and open fractures; indicating the epidote-filled shear fractures formed during the earliest phase of brittle deformation. Assuming a geothermal gradient of $20^{\circ}-30^{\circ} \mathrm{C} / \mathrm{km}$ the epidote-filled faults are interpreted as having formed at depths of between 7 and $15 \mathrm{~km}$.

At the tens of meters scale the mylonite foliation, adjacent to the JF fault core, is rotated $20^{0}$ clockwise. Coincident with rotation away from the main orientation are the tens of centimeter long epidote-filled fractures, and along fault strike to the SW are the longest epidote-filled faults observed in the study site (Fig. 2a). We suggest that this concentration of epidote bearing structures is associated with the rotation of foliation at the 10's meter scale. Folds acted as heterogeneities on which fractures localized, similar to the centimeter and meter scale ductile shear zones. These processes resulted in the formation of an epidote-bearing fault and zone of epidote fault strands and attendant off-fault epidote fractures prior to formation of the JF (Fig. 11b).

The presence of epidote in the JF fault core matrix and as epidote veins in breccia clasts suggests that the JF localized on a pre-existing epidote-rich fault (Fig. 11c). The absence of epidote-filled fractures or larger epidote remnants in the JF fault core suggests the JF accumulated sufficient slip to fully rework the epidote-rich fault material, via attrition and cataclasis. Therefore we propose the epidote-associated deformation phase ceased either prior to, or in the early stages of, JF development. The abundance of pseudotachylyte in the JF indicates fault slip at mid-crustal levels under high shear stress conditions (Sibson and Toy, 2006). The lack of mineralisation suggests dry conditions (at least transiently), consistent with high effective stresses that promote frictional melting. In the JF damage zone the annealed unmineralised fractures cross-cut the epidote-filled fractures and likely formed in the same stage as the pseudotachylyte. Pseudotachylyte generation 
strongly welded and annealed the JF fault breccia (Fig. 11d). The annealed fracture surfaces indicate that the surrounding rock volume was also indurated post-displacement. As stated previously we are unable to determine the mechanism of fracture annealing however, experimental studies of closed fractures in seismogenic fault damage zones (e.g Tenthorey and Cox, 2006; Tenthorey and Fitz Gerald, 2006) suggest fractures may have been healed by hydrothermal reactions and mineral precipitation. Furthermore, these studies find a significant increase in cohesive strength of fault zones as a consequence of the healing process (Tenthorey and Cox, 2006).

A regional apatite fission-track study (Morais Neto et al., 2009), including a sample location adjacent to our study site, indicates two past cooling events. The first event cooled through $100^{\circ} \mathrm{C}$ at c. $100 \mathrm{Ma}$ and a second since $20 \mathrm{Ma}$ cooling through $60^{\circ} \mathrm{C}$ (Fig. 12). For a geothermal gradient of $20^{0}-30^{\circ} \mathrm{C} / \mathrm{km}$ (cf. Lisker 2004) the event at $100 \mathrm{Ma}$ indicates when rock now exposed at surface was at depths of $3-5 \mathrm{~km}$. Observations of the JF fault rocks suggest they formed at $>200^{\circ} \mathrm{C}$ and therefore by 100Ma, thus the JF was active during the Cretaceous rifting (Kirkpatrick et al., 2013).

The final deformation phase formed open, unmineralised, fractures, but did not reactivate the JF. None of the open fractures cut the fault breccia or fault walls. Instead, open shear fractures initiated either at the edge of the welded JF damage zone or on existing ductile or epidote-filled shear fractures outside the JF fault zone (Fig. 11e). Therefore we propose that mechanical contrasts created by structural heterogeneities, from centimeter scale ductile shear zones to the ten's meter scale indurated JF fault core, acted as sites of joint initiation. The presence of dextral and sinistral apparent shear sense indicators on fractures with near-vertical fracture dip, suggest the open fractures formed at shallow depths in a stress field consistent with normal fault slip. These open fractures may have resulted from the phase of exhumation suggested by Nóbrega et al. (2005) and Morais-Neto et al. (2009), thought to have occurred at $\sim 20$ Ma.

Our model demonstrates how temporally evolving deformation conditions can generate complex, hierarchical fault architectures by forming generations of deformation structures that vary in their mechanical and geometric properties. Each structure generation imparts a particular mechanical heterogeneity to the host rock that influences the spatial distribution and geometry of later structures. For example, the formation of pseudotachylyte in the JF indurated the fault core, which subsequently acted as a stiff inclusion in the country rock. Furthermore, each generation of deformation structures imparted different hydraulic architectures (Fig. 11). The earliest flowing structures were the epidote-bearing fractures, which are likely to have been mineralized during the early stages of deformation associated with the JF (Fig. 11b). Abundant epidote in the fault core 
cataclasites of the JF attests to fluid flow also occurring in the fault core during deformation (Fig.

362 11b) Pseudotachylyte welding of the JF in the later stages of development resulted in a very low

363 permeability fault core, with flow focused in the surrounding fractured damage zone that was

364 created during fault growth (Fig. 11c). Modern flow occurs at depth along the long open shear

365 fractures and fracture zones that extend from the edge of the annealed JF fault damage zone (Fig.

366 11e). These act like a secondary hydraulically-conductive fault zone, adjacent to the original fault

367 damage zone. This secondary zone surrounds the annealed fault damage zone and is far wider than

368 would be predicted using fault scaling relationships; this and the implications for developing

369 predictive flow models are discussed below.

\section{5. Discussion}

371 The role of pre-existing structures in influencing fracture and fault formation has been previously 372 recognized (Crider and Peacock, 2004). Moreover, it is widely accepted that faults are inherently 373 weak and, as pre-existing weaknesses, will be reactivated in subsequent deformation events (Butler 374 et al., 2008; Holdsworth et al., 2001). However, what has not been examined in depth is the affect 375 evolving deformation conditions (stress state, temperature, availability of fluid) have on structure 376 formation during successive deformation phases. As conditions change so to do the deformation 377 processes, and hence the mechanical and geometrical properties of the resultant deformation structures. Thus each generation of structure exerts a distinct influence upon the formation of successive structures, acting as mechanical heterogeneities that control the geometrical attributes of new structures in a particular manner. Ultimately as deformation occurs in an evolving tectonic setting the degree of mechanical and structural heterogeneity, and thereby the complexity of the fault zone architecture increases, but not in a manner that would be predicted from conventional fault scaling relationships or fault zone models.

384

Fault scaling relationships indicate broad positive correlations between increasing fault displacement and deformation in the form of increasing fault core and damage zone width (Shipton et al., 2006; Childs et al., 2009) and increasing fracture density in the damage zone (Chester and Chester, 2000; Wilson et al., 2003), as well as decreasing damage zone fracture density with increasing distance from the fault (Schultz and Evans, 1998; Sleight et al., 2001; Chester et al., 2004; Savage and Brodsky, 2011) with a coincident decrease in bulk permeability (Mitchell and Faulkner, 2012). However, fault-scaling relationships provide only a generalized description of fault zone attributes (Manzocchi et al., 2010), for example in the case of fault width there are three orders of magnitude scatter for any value of displacement (Shipton et al., 2006). Furthermore, global scaling relations simplify fault zone geometry by omitting factors such as spatial or temporal 
394

variations in rock mechanical properties. Nevertheless despite these limitations these relationships are frequently applied in reservoir flow models. (Yielding et al., 1997; Hesthammer \& Fossen, 2000; Myers et al., 2007; Jolley et al., 2007; Slightham, 2012).

Models of fault zone and hydraulic architecture in crystalline rocks commonly assume an intensely fractured fault and damage zone that forms a high permeability corridor relative to the low permeability host rock (Caine et al., 1996; Evans et al., 1997; Younes et al., 1998; Slightam, 2012); although the behaviour of the fault zone as either a conduit or barrier to flow will depend on a variety of factors, for example the stress state relative to fracture orientation (Henrikson and Braathen, 2006; Agosta et al., 2010) and mineralisation (Eichhubl et al., 2009). Fault zones in crystalline rock are generally assumed to be mechanically weak zones and thus easily reactivated, making them preferential flow paths that may exhibit multiple mineralisation phases (Le Garzic et al., 2011). In a strongly anisotropic rock such as mylonite the tectonic foliation is suggested to exert a significant influence on the location and geometry of brittle faults (Beacom et al., 2001; Butler et al., 2008), as the foliation creates planes of weakness that can be exploited by fracturing (Shea and Kronenberg, 1993).

Fracture network models are constructed from statistical descriptions of fracture set attributes (length, orientation, spacing) obtained from site-specific seismic surveys, outcrops and boreholes (Aliverti et al., 2003; Degnan et al., 2003; Sanders et al., 2003). However, seismic surveys even of the highest resolution are incapable of imaging meter-scale fractures, while outcrop and borehole data is unavoidably sparse and incomplete (Belayneh et al., 2009). Thus the fracture network model may not fully capture the complexity of the fracture pattern or may overlook important hydraulic conduits.

Although scaling laws and generic fault models are useful, we have shown the impact that temporal and spatial variation in rock mechanical heterogeneity has on structure evolution and as a result the hydraulic architecture of fault-related fracture systems. Our data demonstrate that structural heterogeneities across a range of length scales and in some cases with a subtle expression, such as the minor ductile shear zones, and not the pre-existing fabric influence the geometrical attributes of successive deformation structures. Tens of centimeters wide ductile shear zones formed at high angles to the regional mylonite foliation. The epidote-filled shear fractures developed parallel to these ductile shear zones and consequently cut the regional foliation at high angles. We suggest that rotations of the mylonitic foliation at the 10's meter scale indicates a broad fold that acted in the same manner as the centimeter scale ductile shear zones, as a mechanical heterogeneity on which epidote shear fractures and later the Jucurutu fault localized. Although at the regional scale the 
Jucurutu fault is parallel to the Piranhas shear zone (Kirkpatrick et al., 2013), at the study site the fault cross-cuts the fabric at low-angles. Continued evolution of deformation conditions resulted in pseudotachylyte cementation and annealing of the Jucurutu fault, and its surrounding damage zone, creating a strong fault zone that was not reactivated in the last phase of deformation. Instead the indurated fault zone presented a mechanical contrast with the host rock that promoted nucleation of open shear fractures along its contact with the gneissic host rock.

In the most recent phase of deformation the geometrical attributes of the open shear fractures are controlled by all three prior generations of deformation structure. Open fractures initiate on the edges of both epidote-filled shear fractures and ductile shear zones. Epidote-filled fractures act as sites of initiation for en echelon arrays of open joints. Open shear fractures up to hundreds of meters long extend from the edge of the indurated Jucurutu Fault. For all prior deformation structures the mechanical contrast between the pre-existing structures and the host rock concentrates stress, promoting open fracture formation. The formation of open joints on ductile shear zones, epidote shear fractures and on the edge of the JF fault zone rather than the reactivation of the main fault surface or off-fault fractures, is inconsistent with the view of weak fault zones being preferentially reactivated in later deformation events.

In this study the evolution of deformation conditions and processes has culminated in the formation of a second hydraulically conductive fault damage zone of open low-offset shear fractures, adjacent to the original Jucurutu fault damage zone. The location and size of which might be overlooked by typical fracture surveys. Line transects perpendicular to the fault indicate fault-related fractures reaching a constant lower limit (the edge of the damage zone) $\sim 60$ meters from the fault (Fig. 8), whereas the high-angle open fractures extend beyond the 150m-wide exposure from the main fault. These low-offset shear fractures would not be identified by seismic surveys, and boreholes would be unlikely to identify them as a fault-related zone. Therefore, the area of greatest permeability would be assumed to occur within the $\sim 120$ m wide damage zone surrounding the JF fault core.

Furthermore, as the width of this wide zone of open fault-related fractures is not directly related to the displacement accrued by the Jucurutu fault, the true lateral extent of the open shear fracture zone may not be predicted from fault scaling relationships. Assuming the Jucurutu fault has a minimum displacement of $150 \mathrm{~m}$, similar to that observed on the Sao Rafael fault, the global scaling relationship for damage zone thickness with displacement (Torabi and Berg, 2011; Savage and Brodsky, 2011) would suggest a maximum damage zone width of $\sim 700 \mathrm{~m}$. However, the linetransect fracture data indicates the limit of the damage zone is $\sim 60 \mathrm{~m}$ either side of the Jucurutu fault giving a total damage zone width of 120 meters, which according to the scaling relationship 
460

461

462

463

464

465

466

467

468

469

470

471

472

473

474

475

476

477

478

479

480

481

482

483

484

485

486

487

488

489

490

491

correlates with a fault displacement of $150 \mathrm{~m}$. Therefore the scaling relationship suggests that the damage zone as defined by the fracture scanline data is most probably the limit of the fault-related fracturing and consequently, the principal hydraulically conductive zone would go unnoticed.

Our proposition that these open fractures are an important along-fault hydraulically-conductive zone is supported by the microseismic data associated with the São Rafael fault (Pytharouli et al., 2011) to the north of the Jucurutu fault (Fig. 1). Microseismic events at São Rafael are triggered by pressure diffusion from the reservoir, thus occurring on open flowing fractures. The microseismicity defines multiple open flowing shear fractures, several hundred meters in length in a longitudinal zone parallel and coincident with the main São Rafael fault trace. These shear fractures have orientations both parallel and at high angles to the São Rafael Fault and the mylonitic foliation. We propose that the 100's meter long open shear fractures observed at the Jucurutu study site are analogous to those at Sao Rafael and, given their length, are potentially significant hydraulically-conductive fractures.

This study shows that the most hydraulically important aspect of the fault system may go undetected or be underestimated. The largest existing fault structures may not be reactivated as commonly expected, and the resulting flow network is not always well described by fault zone scaling relationships. Hence, an important consideration in the development of realistic fracture flow models is the mechanical heterogeneities of the rock across a range of scales and their impact on the fracture formation and geometrical attributes.

We have demonstrated that deformation under multiple conditions alters the mechanical properties of structures and leads to an increase in structural complexity. Recent improvements in thermochronology have shown that episodic burial and exhumation histories may be more common than monotonic cooling and unroofing (e.g Holford et al., 2010). Therefore when investigating recent brittle fault formation in a long lived tectonic setting we should consider previous deformation phases, conditions and resultant structures as they may have a bearing on the formation and architecture of the more recent faults and fracture networks.

\section{Conclusions}

Temporal changes in deformation conditions (pressure, temperature and availability of fluids) and thus deformation processes in the study area created generations of structures that differ in their mechanical and geometric attributes. These structures behaved as mechanical heterogeneities within the host rock, strongly influencing the spatial distribution and geometrical attributes of structures formed in later deformation events. Mechanical contrasts at a range of scales and types, from 
centimeter-wide ductile shear zones to the 100's meter-scale welded Jucurutu fault, influence the formation of subsequent structures; culminating in the generation of extensive open shear fractures and fracture zones. Hence, deformation under evolving conditions produces an increasingly mechanically heterogeneous and complex fracture system architecture.

In addition to differing frequency and spacing of deformation structures, the successive deformation events were characterized by different hydraulic structures. The earliest flowing structures, the epidote-filled fractures, are perpendicular to the mylonitic foliation. Hence, rather than reactivating the regional foliation the epidote-filled fractures formed parallel to foliation in centimeter-wide ductile shear zones. The Jucurutu fault cross-cuts the mylonitic fabric at a low angle and both fault core and damage zone were flow conduits. However, pseudotachylyte welding created a highly indurated, low-permeability fault core and damage zone. Conventional methods for predicting shear fracture and fracture geometric attributes would focus on applying fault-scaling relationships to the larger brittle structures. Thus the most recent phase of fracturing would be assumed to have reactivated the Jucurutu fault and increased the fracture density in, and the width of, the Jucurutu fault zone. The open shear fractures and joints, that are controlling flow at depth, lie outside the damage zone of fault related fractures which would, by current fault models, define the lateral extent of the Jucurutu fault zone. The development of open joints and shear fractures at the edge of the indurated Jucurutu fault result in a fault-parallel zone of hydraulically-conductive fracturing adjacent to the original, now indurated, fault damage zone with a lateral extent that exceeds $150 \mathrm{~m}$. Thus the most hydraulically important part of the fault system is likely to be unaccounted for in current approaches to fault scaling and fracture modelling.

Our study demonstrates the importance of considering the geological history of an area, the previous deformation conditions and processes, and thus the mechanical and geometric attributes of the structures formed as they exert a strong influence on the formation of later structures. We show that in basement terrains or settings that have experienced multiple deformation events, the complexity and longevity of the deformation history is an important consideration in developing accurate fracture and fault models for fluid flow prediction.

\section{Acknowledgements}

AS, ZS, RL, SP and JK were supported by NERC grant NE/E005365/1. AFdN and FHRB were supported by INCT/CNPq Petroleum Geophysics, INCT/CNPq Tectonic Studies and CNPq grant 483349/2007-0.Thanks to K. Dobson for her valuable assistance in the field. 


\section{References}

526 Agosta, F., Alessandroni, M., Antonellini, M., Tondi, E., \& Giorgioni, M. 2010. From fractures to 527 flow: A field-based quantitative analysis of an outcropping carbonate reservoir. Tectonophysics, 528 490, 197-213, doi:10.1016/j.tecto.2010.05.005

529 Aliverti, E., Biron, M., Francesconi, A., Mattiello, D., Nardon, S. \& Peduzzi, C. 2003. Data

530

531

532

533

534

535

536

537

538

539

540

541

542

543

544

545

546

547

548

549

550

551

552

553

554

555 analysis, processing and 3D fracture network simulation at wellbore scale for fractured reservoir description. In: Ameen, M. (ed) Fracture and In-situ Stress Characterization of Hydrocarbon Reservoirs, Geological Society, London, Special Publications, 209, 27-37.

Arthaud, M.H., Caby, R., Fuck, R.A., Dantas, E.L., \& Parente, C.V., 2008. Geology of the northern Borborema Province, NE Brazil and its correlation with Nigeria, NW Africa. In: Pankhurst, R.J., Trow, R.A.J., Brito Neves, B.B., de Wit, M.J. (eds) West Gondwana, Pre-Cenozoic Correlation across the South Atlantic Region.. Geological Society, London, Special Publications, 294, 49-67.

Beacom, L. E., Holdsworth, R. E., McCaffrey, K. J. W., \& Anderson, T. B. 2001. A quantitative study of the influence of pre-existing compositional and fabric heterogeneities upon fracture zone development during basement reactivation,. In: Holdsworth, R. E., Strachan, R. A., and Magloughlin, J.F. (eds) The Nature and Tectonic Significance of Fault Zone Weakening. Geological Society, London, Special Publications, 186, 195-211.

Belayneh, M. W., Matthai, S. K, Blunt, M. J. \& Rogers, S. F. 2009. Comparison of deterministic with stochastice fracture models in water-flooding simulations. AAPG Bulletin 93, 1633-1648.

Brito Neves, B.B., Santos, E.J., \& Van Schmus, W.R. 2000. Tectonic history of the Borborema Province, Northeastern Brazil. In: Cordani, U.G., Milani, E.J., Thomaz Filho, A., Campos, D.A. (Eds.), Tectonic Evolution of South America. 31st Inter- national Geological Congress, Rio de Janeiro,151.-182.

Bruhn, R. L., Parry, W. T., Yonkee, W. A. \& Thompson, T. 1994. Fracturing and hydrothermal alteration in normal fault zones, Pageoph., 142, 609-644.

Butler, R. W. H., Bond, C. E., Shipton, Z. K., Jones, R. R., \& Casey, M. 2008. Fabric anisotropy controls faulting in the continental crust. Journal of the Geological Society, London 165, 449-452, doi:10.1144/0016-76492007-129.

Caine, J.S., Evans, J.P. \& Forster, C.B. 1996. Fault zone architecture and permeability Structure. Geology, 24, 1025-1028.

Chester, F.M., and Chester, J.S. 2000. Stress and deformation along wavy frictional faults. Journal 
of Geophysical Research, 105, B10, 23421-23430.

557 Chester, F.M., Chester, J.S., Kirschner, D.L., Schulz, S.E., \& Evans, J.P. 2004. Structure of large-

558 displacement, strike-slip fault zones in the brittle continental crust. In: Karner, G.D., Taylor, B.,

559 Driscoll, N.W., and Kohlstedt, (eds) Rheology and Deformation in the Lithosphere at Continental

560 Margins, Columbia University Press, New York, 2004.

561 Childs C., Manzocch T., Walsh J.J., Bonson C.G., Nicol A., \& Schöpfer M. P. J. 2009. A geometric

562 model of fault zone and fault rock thickness variations. Journal of Structural Geology, 31, 117-127.

563 Cooke, M.L., Simo, J.A., Underwood, C.A., \& Rijken, P. 2006. Mechanical stratigraphic controls

564 on fracture patterns within carbonates and implications for groundwater flow. Sedimentary Geology

565 184, 225-239.

566 Crider, J. G. \& Peacock, C. P. 2004. Initiation of brittle faults in the upper crust: a review of field

567 observations. Journal of Structural Geology, 26, 691.-707, doi:10.1016/j.jsg.2003.07.007.

568 d'Alessio, M., \& Martel, S.J. 2005. Development of strike-slip faults from dikes, Sequoia National

569 Park, California. Journal of Structural Geology, 27, 35-49.

570 Davatzes N. C., Eichhubl P., \& Aydin A. 2005. Structural evolution of fault zones in sandstone by 571 multiple deformation mechanisms: Moab fault, southeast Utah. GSA Bulletin, 117, 135-148; doi:

$57210.1130 / \mathrm{B} 25473.1$

573 De Castro, D. L., Bezerra, F. H. R., \& Branco, R. M. G. C. 2008. Geophysical evidence of crustal 574 heterogeneity control of fault growth in the Neocomian Iguatu basin, NE Brazil. Journal of South 575 American Earth Sciences. ,26, 271-285.

576 De Castro, D. L., Bezerra, F. H. R., Sousa, M. O. L., \& Fuck, R. A. 2012. Influence of

577 Neoproterozoic tectonic fabric on the origin of the Potiguar Basin, northeastern Brazil and its links

578 with West Africa based on gravity and magnetic data. Journal of Geodynamics , 54, 29-42,

579 dx.doi.org/10.1016/j.jog.2011.09.002

580 Degnan, P.J., Littleboy, A.K., McL. Lichie, U., Jackson, C. P., \& Watson, S. P. 2003. Fracture-

581 dominated flow in the Borrowdale Volcanic Group at Sellafield, NW England: the identification of

582 potential flowing features, development of conceptual models and derivation of effective

583 parameters. In: Petford, N. \& McCaffrey, K. J. W. (eds) Hydrocarbons in Crystalline Rocks,

584 Geological Society, London, Special Publications, 214, 197-219.

585 Di Toro, G., \& Pennacchioni, G. 2005. Fault plane processes and mesoscopic structure of a strong586 type seismogenic fault in tonalities (Adamello batholith, Southern Italian Alps). Tectonophysics, $587 \quad 402,55-80$ 
Eichhubl, P., Davatzes, N.C., Becker, S.P., 2009, Structural and diagenetic control of fluid migration and cementation along the Moab Fault, Utah. AAPG Bulletin, 93, 653-681

590 Evans, J.P., Forster, C.B., \& Goddard, J.V. 1997. Permeability of fault-related rocks and

591 implications for hydraulic structure of fault zones. Journal of Structural Geology, 19, 1393-1404.

592 Ferrill, D.A., and Morris, A.P., 2008. Fault zone deformation controlled by carbonate mechanical 593 stratigraphy, Balcones fault system, Texas. AAPG Bulletin, 92, 359-380.

594 Fisher, M.P. and Polansky, A. 2006. The influence of flaws on joint spacing and saturation: results 595 of one-dimensional mechanical modelling, Journal of Geophysical Research, 111, B07403, doi: 10.1029/2005JB004115.

597 Guilbert, J.M., and Park, C.F. 1986. The Geology of Ore Deposits. Freeman and Company, New 598 York.

599 Griffith, W.A., Mitchell, T.M., Renner, J., \& Di Toro, G. 2012. Coseismic damage and softening of 600 fault rocks at seismogenic depths, Earth and Planetary Science Letters, 353, 219-230.

601 Henrikson, H., and Braathen, A., 2006. Effects of fracture lineaments and in situ stress on 602 groundwater flow in hard rocks: a case study from Sunnfjord western Norway. Hydrogeological 603 Journal, 14, 444-461.

604 Hesthammer, J. \& Fossen, H. 2000. Uncertainties associated with fault sealing analysis. Petroleum 605 Geoscience, 6, 37-47.

606 Holdsworth, R.E., Stewart, M., Imber, J., \& Strachan, R.A. 2001. The structure and rheological 607 evolution of reactivated continental fault zones: a review and case study. In: Miller, J.A., 608 Holdsworth, R.E., Buick, I.S. \& Hand, M. (eds) Continental Reactivation and Reworking, 609 Geological Society, London, Special Publications, 184, 115-137.

610 Holford, S.P., Green, P.F., Hillis, R.R., Underhill, J.R., Stoker, M.S., \& Duddy, I.R. 2010. Multiple 611 post-Caledonian exhumation episodes across NW Scotland revealed by apatite fission-track 612 analysis. Journal of the Geological Society, London, 167, 675-694, doi:10.1144/0016-76492009613167.

614 Johansen, T.E.S., Fossen, H., \& Kluge, R. 2005. The impact of syn-faulting porosity reduction on 615 damage zone architecture in porous sandstone: an outcrop example from the Moab Fault, Utah.

616 Journal of Structural Geology, 27, 1469-1485.

617 Jolley, S.J., Dijk, H., Lamens, J.H., Fisher, Q.J., Manzocchi, T., Eikmans \& Huang, Y. 2007.

618 Faulting and fault sealing in production simulation models: Brent Province, northern North Sea.

619 Petroleum Geoscience, 13, 321-340 
620 Kirkpatrick, J.D., Shipton, Z.K., Evans, J.P., Micklethwaite, S., Lim, S.J., \& McKillop, P. 2008.

621 Strike-slip fault terminations at seismogenic depths: The structure and kinematics of the Glacier

622 lakes fault, Sierra Nevada United States. Journal of Geophysical Research, 113, B04304,

623 doi:10.1029/2007JB0053111.

624 Kirkpatrick'J. D., Bezerra, F.H.R., Shipton Z.K., do Nascimento A.F., Pytharouli S.I., Lunn R.J. \&

625 Soden, A.M. 2013. Scale-dependent influence of pre-existing basement shear zones on rift faulting:

626 a case study from northeast Brazil. Journal of the Geological Society, London, 170, 237-247.

627 Koning, T., 2003. Oil and gas production from basement reservoirs: examples from Indonesia, USA

628 and Venezuela. In: Petford, N. \& McCaffrey, K. J. W. (eds) Hydrocarbons in Crystalline Rocks,

629 Geological Society, London, Special Publications, 214, 83-92.

630 Laubach, S.E., Olson, J.E., \& Gross, M.R. 2009. Mechanical and fracture stratigraphy. AAPG

631 Bulletin, 93, 1413-1426.

632 Le Garzic E., de L’Hamaide T., Diraison M., Géraud Y., Sausse J., de Urreiztieta M., Hauville B.,

633 \& Champanhet J.-M., 2011. Scaling and geometric properties of extensional fracture systems in the

634 proterozoic basement of Yemen. Tectonic interpretation and fluid flow implications. Journal of

635 Structural Geology, 33, 519-536.

636 Lisker, F. 2004. The Evolution of the Geothermal Gradient from Lambert Graben and Mahanadi

637 Basin - A Contribution to the Indo-Antarctic Rift Debate. Gondwana Research, 7(2), 363-373.

638 Manzocchi, T., Childs, C., \& Walsh, J.J. 2010. Fault and fault properties in hydrocarbon flow

639 models. Geofluids, 10, 94-113.

640 Matos, R. M. D. 1992. The northeast Brazilian rift system. Tectonics, 11, 766-791.

641 Mauldon, M., Dunne, W.M., \& Rohrbaugh Jr., M.B. 2001. Circular scanlines and circular windows:

642 new tools for characterizing the geometry of fracture traces. Journal of Structural Geology, 23, $247-$

643258.

644 McConaughy, D.T., \& Engelder, T. 2001. Joint initiation in bedded clastic rocks, Journal of

645 Structural Geology, 23, 203-221.

646 Moir, H., Lunn R.J., Shipton Z.K., \& Kirkpatrick, J.D., 2010. Simulating brittle fault evolution

647 from networks of pre-existing joints within crystalline rock, Journal of Structural Geology, 32

$648 \quad$ 1742-1753. doi:10.1016/j.jsg.2009.08.016

649 Moir H., Lunn, R.J., Micklethwaite, S. \& Shipton Z.K. 2013. Distant off-fault damage and gold

650 mineralization: The impact of rock heterogeneity. Tectonophysics, 608, 461-46.

651 doi10.1016/j.tecto.2013.08.043. 
652

653

654

655

656

657

658

659

660

661

662

663

664

665

666

667

668

669

670

671

672

673

674

675

676

677

678

679

680

681

682

Morais Neto, J. M., Hegarty, K. A., Karner, G. D., \& Alkmim 2009. Timing and mechanisms for the generation and modification of the anomalous topography of the Borborema Province, northeastern Brazil. Marine and Petroleum Geology, 26, 1070-1086, doi:10.1016/j.marpetgeo.2008.07.002.

Mitchell, T.M., \& Faulkner, D.R. 2012. Towards quantifying the matrix permeability of fault damage zones in low porosity rock., Earth and Planetary Science Letters, 339-349, 24-31.

Myers, R.D., Allgood, A., Hjellbakk, A., Vrolijk, P. \& Briedis, N. 2007. Testing fault transmissibility predictions in a structurally dominated reservoir: Ringhorne Field, Norway. In: Jolley, S.J., Barr, D., Walsh, J.J. \& Knipe, R.J. (eds) Structurally Complex Reservoirs. Geological Society, London, Special Publications, 292, 271-294.

Nóbrega, M. A., Sá, J. M., Bezerra, F. H. R., Hadler Neto, J. C., Iunes, P. J., Oliveira, S. G., Saez, C. A. T. \& Lima Filho, F.P. 2005. The use of apatite fission track thermochronology to constrain fault movements and sedimentary basin evolution in northeastern Brazil. Radiation Measurements, 39, 627-633.

Pollard, D. D. \& Aydin, A. A. 1988. Progress in understanding jointing over the past century. Geological Society of American Bulletin, 100, 1181-1204.

Pytharouli S. I., Lunn R. J., Shipton Z. K., Kirkpatrick J., D., \& do Nascimento A. F. 2011. Microseismicity illuminates fluid pathways in the shallow crust. Geophysical Research Letters, 38, L02402, doi:10.1029/2010GL045875.

Rotevatn, A., \& Fossen, H. 2011. Simulating the effect of subseismic fault tails and process zones in a siliciclastic reservoir analogue: implications for aquifer support and trap definition. Marine and Petroleum Geology, 28, 1648-1662.

Sanders, C. A. E., Fullarton L. \& Calvert, S. 2003. Modelling fracture systems in extensional crystalline basement. In: Petford, N. \& McCaffrey, K. J. W. (eds) Hydrocarbons in Crystalline Rock., Geological Society, London, Special Publications, 214, 7-33.

Sausse, J., Fourar, M. \& Genter, A. 2006. Permeability and alteration within the Soultz granite inferred from geophysical and flow log analysis. Geothermics, 35, 544-560, doi:

\subsection{6/j.geothermics.2006.07.003.}

Savage, H.M., \& Brodsky, E.E. 2011. Collateral damage: Evolution with displacement of fracture distribution and secondary fault strands in fault damage zones. Journal of Geophysical Research, 116, B03405, doi:10.1029/2010JB007665. 
Schultz, S.E., \& Evans, J.P. 1998. Spatial variability in microscopic deformation and composition of the Punchbowl fault, southern California: implications for mechanisms, fluid-rock interaction, and fault morphology. Tectonophysics, 295, 223-244.

Schutter, R. S. 2003. Hydrocarbon occurrence and exploration in and around igneous rocks. In: Petford, N. \& McCaffrey, K. J. W. (eds) Hydrocarbons in Crystalline Rocks. Geological Society, London, Special Publications, 214, 7-33.

Shackleton, J.R., Cooke, M.L., \& Sussman, A.J. 2005. Evidence of temporally changing mechanical stratigraphy and effects on joint-network architecture. Geology, 33,101-104.

Shea, W. T. \& Kronenberg, A. K. 1993. Strength anisotropy of foliated rocks with varied mica contents. Journal of Structural Geology, 15, 1097-1121.

Shipton, Z.K., Soden, A.M., Kirkpatrick, J.D., Bright, A.M., \& Lunn, R.J. 2006 How thick is a fault? Fault displacement-thickness scaling revisited. In Abercrombie, R. (ed.), Earthquakes: Radiated Energy and the Physics of Faulting. Geophysical Monograph Series, 170, 193-198. Sibson, R. H., \& Toy V. G. 2006. The habitat of fault-generated pseudotachylyte: presence vs. absence of friction-melt. In R. E. Abercrombie, A. McGarr, G. di Toro and H. Kanamori (eds), Earthquakes: Radiated Energy and the Physics of Faulting. American Geophysical Monograph, $170153-166$.

Sleight, J. M., McCaffrey, K. J. W. \& Holdsworth, R. E. 2001. Micro to regional scale fracture characteristics from the More Trondelag Fault Complex, Central Norway. Hydrocarbons in Crystalline rocks. Abstract book, London.

Slightam C. 2012. Characterising seismic-scale faults pre- and post- drilling; Lewisian Basement, West of Shetlands. In Spence, G. H., Redfern, J., Aguilera, R., Bevan, T. G., Cosgrove, J. W., Couples, G. D. \& Daniel, J.-M. (eds), Advances in the Study of Fractured Reservoirs. Geological Society, London, Special Publications, 374, doi: 10.1144/SP374.6

Soden, A. M., \& Shipton, Z. K. 2013. Dilational fault zone architecture in a welded ignimbrite: The importance of mechanical stratigraphy. Journal of Structural Geology. 51, 156-166, doi: 10.1016/j.jsg.2013.02.001.

Tenthorey, E., \& Cox, S.F., 2006. Cohesive strengthening of fault zones during the interseismic period: An experimental study. Journal of Geophysical Research, 111, doi: 
Tenthorey, E., \& Fitzgerald, J.D., 2006. Feedback between deformation, hydrothermal reaction and permeability evolution in the crust: Experimental insights. Earth and Planetary Science Letters, 247, 117-129.

716 Tien, Y. M., Kuo, M. C. \& Juang, C. H. 2006. An experimental investigation of the failure 717 mechanism of simulated traversely isotropic rocks. International Journal of Rock Mechanics \& 718 Mining Sciences, 43, 1163-1181.

719 Torabi, A. \& Berg, S. S. 2011. Scaling of fault attributes: A review. Marine and Petroleum 720 Geology, 28, 1444-1460.

721 Vauchez, A., Pacheco-Neves, S., Caby, R., Corsini, M., Egydio-Silva, M., Arthaud, M., \& Amaro, 722 V. 1995. The Borborema shear zone system. Journal of South American Earth Sciences, 8, $247-$ 723266

724 Wilson, J.E., Goodwin, L.B., \& Lewis, C.J. 2003. Deformation bands in nonwelded ignimbrites: 725 petrophysical controls on fault-zone deformation and evidence of preferential fluid flow, Geology $72631,837-840$.

Yielding, G., Freeman, B. \& Needham, D.T. 1997. Quantitative fault seal prediction. AAPG

728 Bulletin, 81, 897-917.

729 Younes, A. I., Engelder, T. \& Bosworth, W. 1998. Fracture distribution in faulted basement blocks:

730 Gulf of Suez, Egypt. In: Coward, M. P., Daltaban, T. S. \& Johnson, H. (eds) Structural Geology in

731 Reservoir Characterization. Geological Society, London, Special Publications, 127, 167-190.

732

734 Figure 1. Map of the Rio Piranhas fault system from satellite images and air photos. The extent of mylonitization associated with the Piranhas shear zone is indicated by cross-hatching. The black arrow indicates the location of observed $150 \mathrm{~m}$ apparent dextral offset of a pluton boundary. (Adapted from Kirkpatrick et al., 2013)

Figure 2. a) Map of study site showing Jucurutu fault (JF); line transects (LT) locations, blue box encloses LT1-5 oriented parallel to JF; areas of fracture data (FD) collection from ridge outcrops that parallel host rock foliation, fracture data was collected along ridge strike. *indicates epidotefilled shear fractures offsetting dykes. Inset: Google Earth satellite image, study area outlined by white box, white arrow indicates JF FC outcrop. b) Typical ridge-like outcrop (FD4) looking southwest. Rucksack ringed bottom right for scale. C) Sub-vertical mylonite foliation d) Rose diagram of foliation strike.

Figure 3. Epidote-filled fractures a) 10's cm long in JF damage zone. Meter-long outside the JF DZ occur as b) en echelon and c) single fracture seeded on ductile shear. Epidote-shear fractures $>5 \mathrm{~m}$ long d) two generations of gouge first generation consists of mylonite clasts in a quartz-epidote- 
chlorite matrix (Kirkpatrick et al., 2013). Second generation composed of epidote clasts in a finegrained red matrix. e) Sinistral sheared dyke with later f) sinistral epidote-filled fracture.

Figure 4. a) Rose diagram of 10's cm long epidote-filled fractures in JF DZ: recorded from LT1-5. b) Stereonet of epidote-filled fractures and shear sense where observed. Grey symbols are epidotefilled shear fractures $>5 \mathrm{~m}$ long, shown in Fig. 2a. Mean mylonite foliation $n=103$ with standard deviation of 13 . Note the epidote-filled fractures strike at a high angle to the mylonite foliation.

Figure 5. a) An approximately $20 \mathrm{~m}$ long strike-parallel section of the Jucurutu fault core exposed in the Piranhas river gulley (location marked $\mathrm{X}-\mathrm{X}^{\prime}$ in fig.2a). b) Fault core width ranges from $1.4 \mathrm{~m}$ to $2 \mathrm{~m}$. No principal slip surface is exposed (presumed weathered out in gully) but breccias are bounded by smooth fault walls. Clasts are randomly orientated and up to $0.5 \mathrm{~m}$ wide. Tape measure is $1 \mathrm{~m}$ long. c) Close up of JF breccia, which is strongly welded by pseudotachylyte. Note epidote fractures within clasts do not cross-cut the purple matrix of the breccia.

Figure 6. Jucurutu fault damage zone. a \& b) High density 10 's $\mathrm{cm}$ scale unmineralised annealed fractures. c) Rose diagram of unmineralised annealed fracture strike from LT1-5, FD 5, $6 \& 7$ and d) poles to annealed fractures for which shear sense indicators were observed.. Note in the JF DZ annealed unmineralised fractures are more common than epidote-filled fractures.

Figure 7. a) View of transition from short, meshwork fracturing developed in the damage zone of the Jucurutu fault to dominantly sub-parallel long open fracture and fracture zones that characterize the area extending from the edge of the damage zone outwards across the rest of the study area. b) Joint intensity data collected using circular scanlines at 4-8m intervals along line transects perpendicular to the JF.

Figure 8. a) Single open fractures transecting FD4. b) Tens of meter long open en echelon fracture zone and c) open en echelon fracture zone and single fractures. All occur $\sim 100 \mathrm{~m}$ outside limit of JF DZ.

Figure 9. Stereonets of open fractures and fracture zones from sample areas FD1-4, 8. Great circle is mean mylonite foliation from each sample area. Open fractures with shear sense indicators are highlighted.

Figure 10. a) En echelon fractures nucleating on a epidote vein (insect b ) c) En echelon open fractures and d) open fractures nucleating on epidote mineralized fractures which themselves overprint ductile shear zones.

Figure 11. Conceptual model of fault and fracture system structural evolution and impact on hydraulic architecture. Temporal evolution of deformation conditions leads to variable deformation processes and hence mechanically and spatially distinct generations of deformation structures.

Figure 12. Temperature time graph indicating timing of ductile and epidote associated deformation phase, upper and lower temperatures for epidote associated deformation (chlorite assemblages) and A-ft temperatures for $100 \mathrm{Ma}$ and $20 \mathrm{Ma}$ cooling events. Time periods indicated by colour boxes - 
795 Cambrian- early Ordovician (purple), Jurassic (green), Cretaceous (blue), Paleogene (yellow) and 796 Neogene (orange)

797 


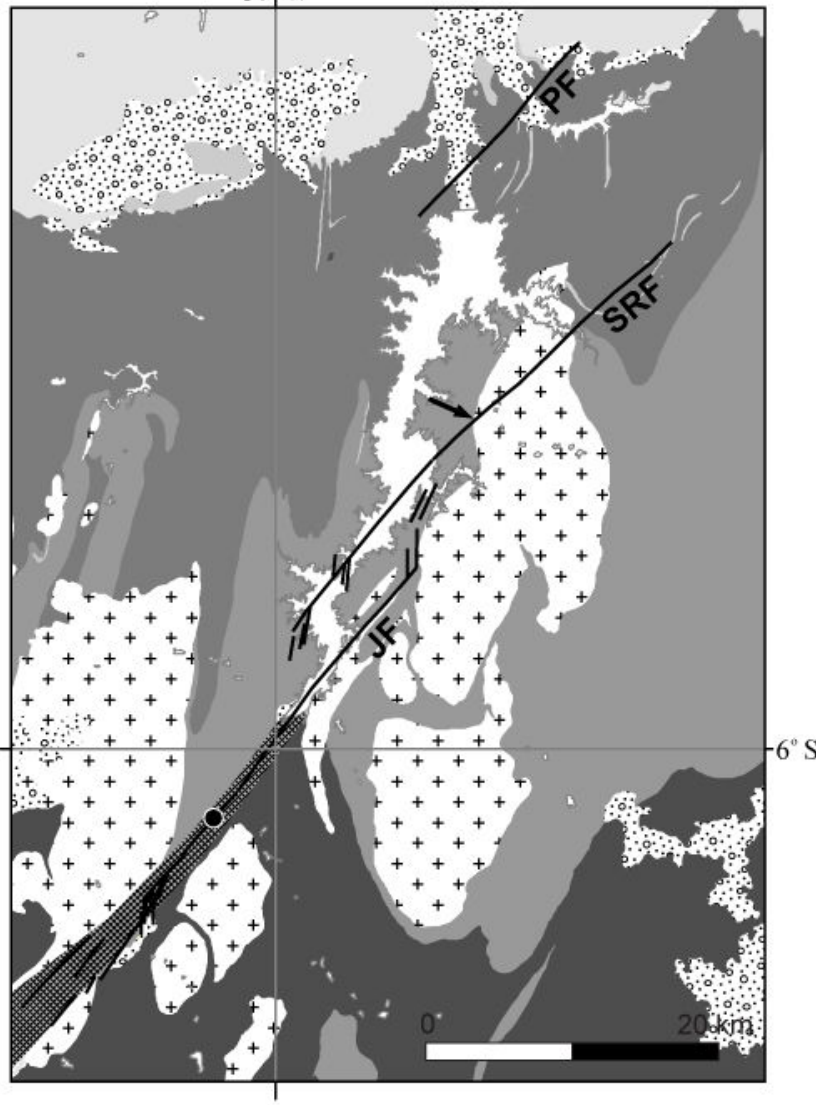

; Barreiras (Eocene) [+ Intrusives (Neoproterozoic)

Cuó(Cretaceous)

Serido'(Neoproterozoic)

Açu (Cretaceous)

Caicó(Palaeoproterozoic)

Extent of mylonitization

/Fault Study site 


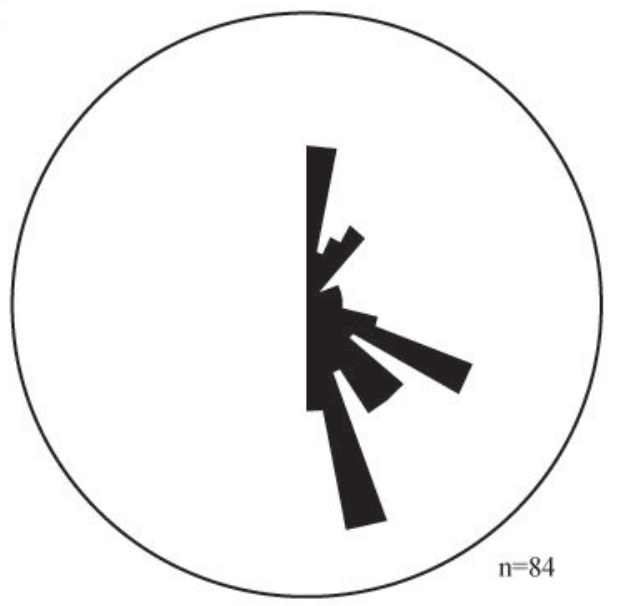

b

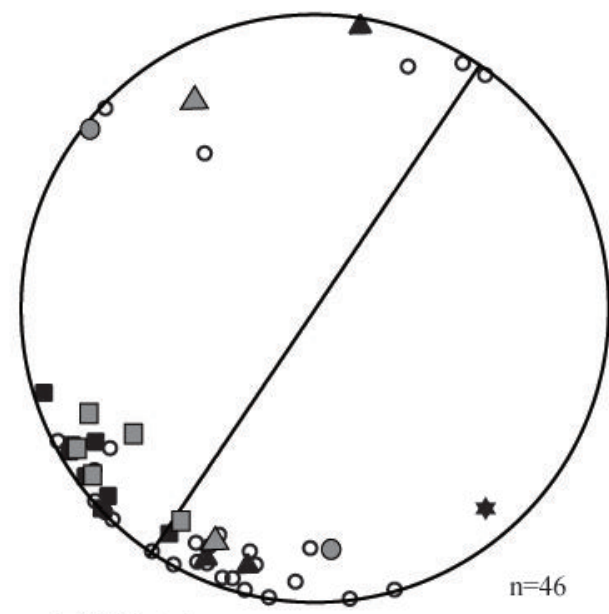

- Sinistral

$\Delta$ Dextral

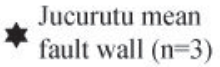

O Unobserved 
a)

Meter's long open fractures with
sub-parallel uniform distribution

JF damage zone with 10 's $\mathrm{cm}$ long

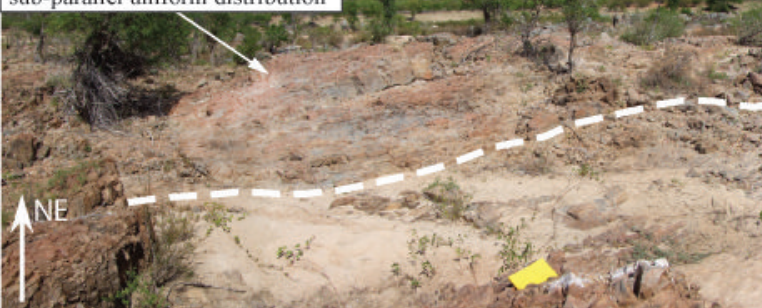

epidote-filled \& annealed unmineralised fractures

b)
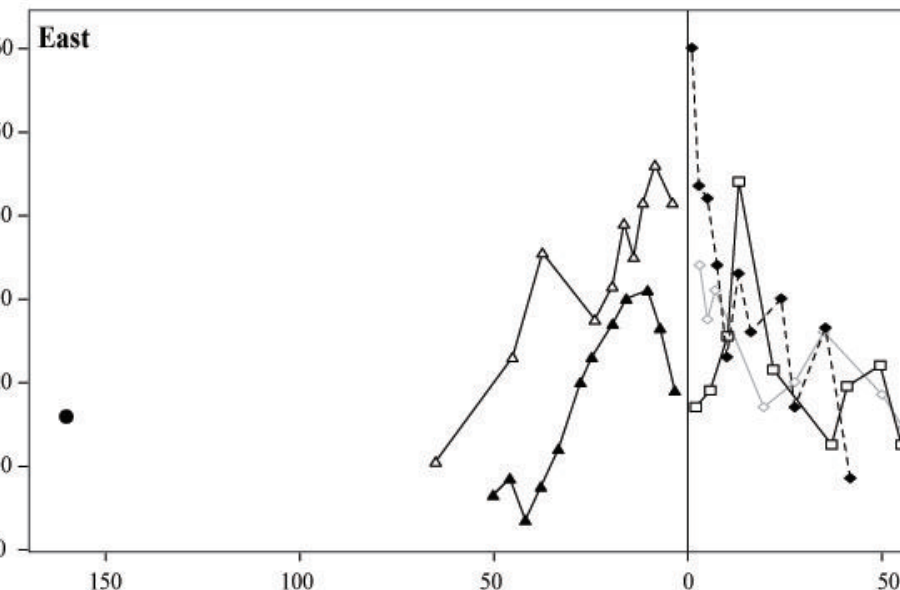

Distance from fault $(\mathrm{m})$

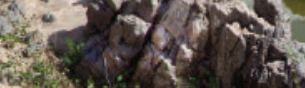

axid

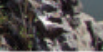






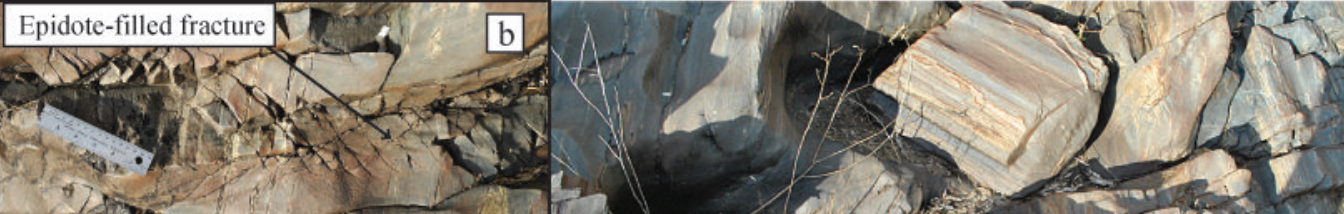

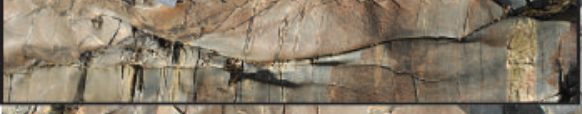

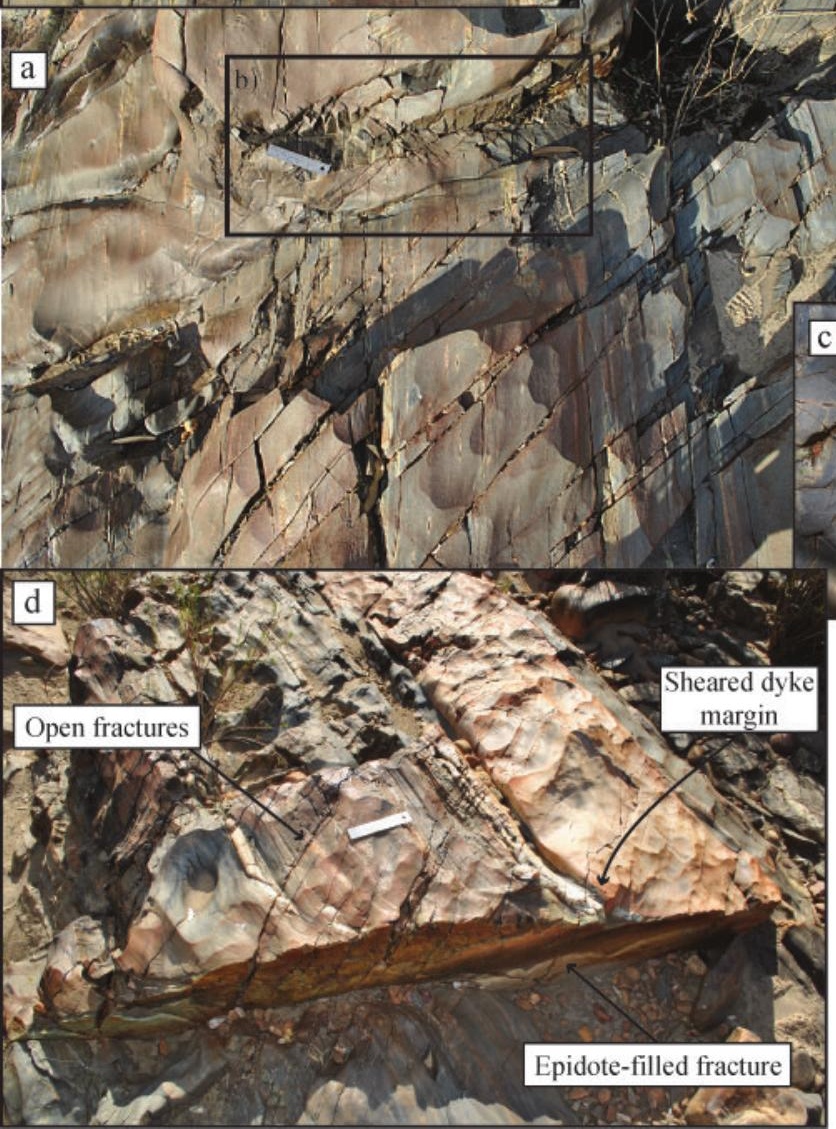

6. bi

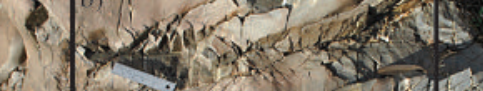

4 ?

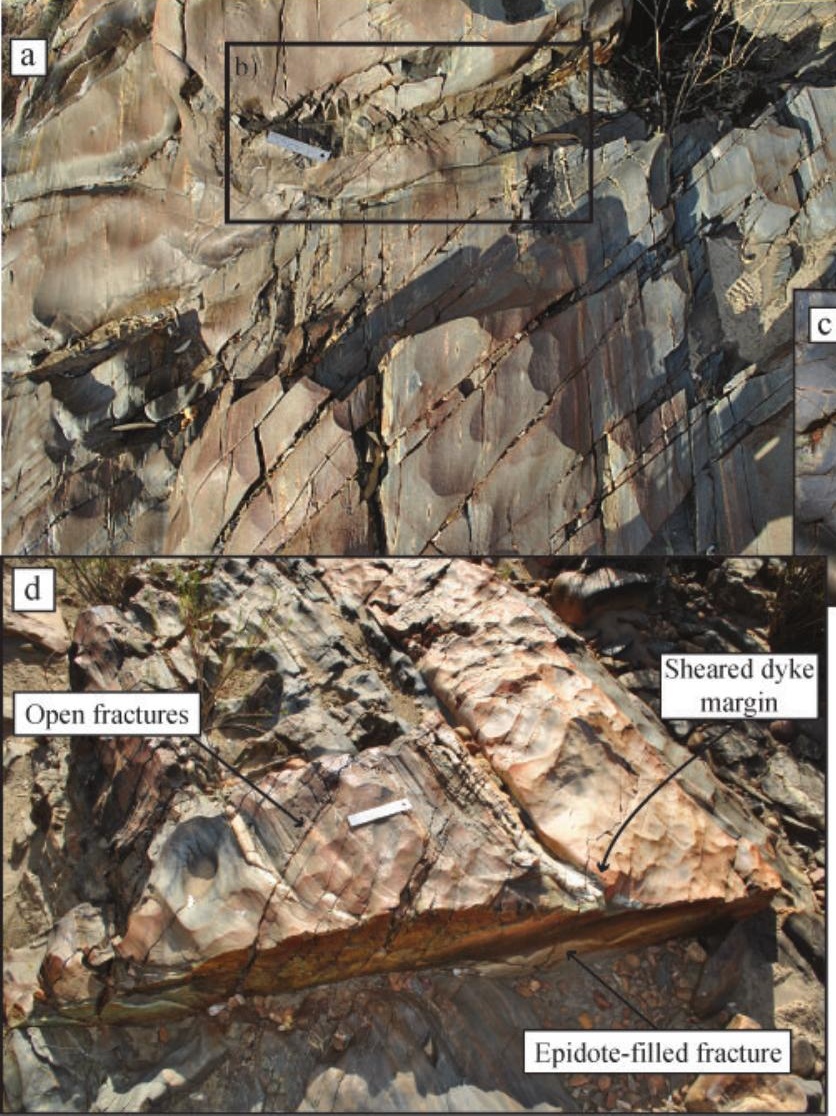


a) Ductile deformation phase

Ductile shear zones formed on $\mathrm{cm}$ to tens meter scale

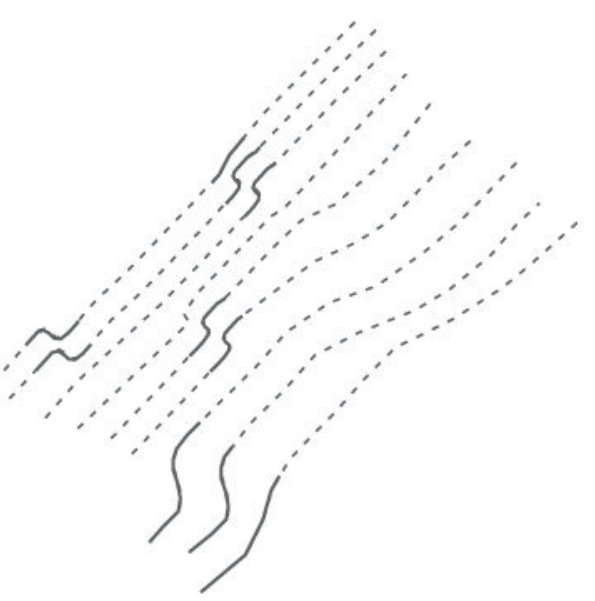

c) Brittle deformation phase II

Strike slip faulting; pseudotach-rich fault core probably low permeability. Flow focused in fractured damage zone

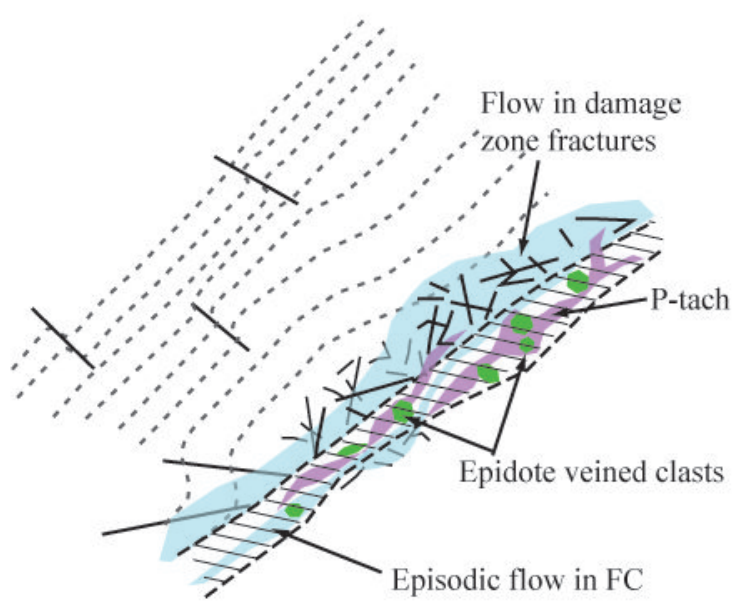

e) Brittle deformation phase III

Open fractures nucleate on edge of highly indurated FC and on epidote and ductile shear zones

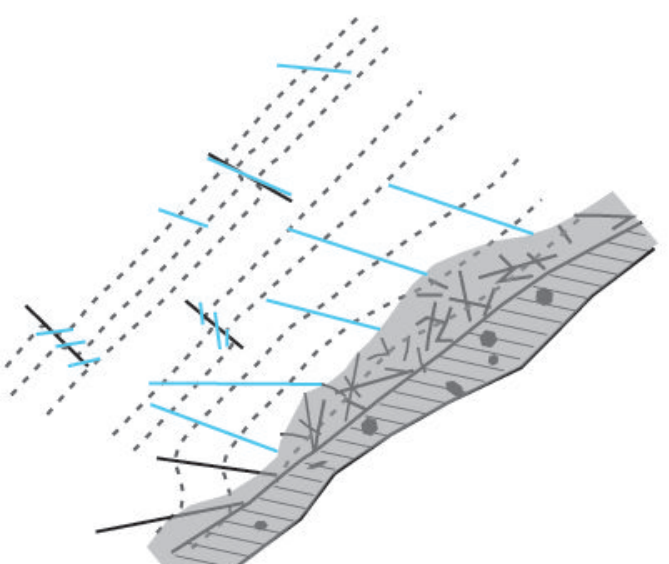

Modern flow in $>100 \mathrm{~m}$ long fractures
Brittle fractures form on ductile shear zones.

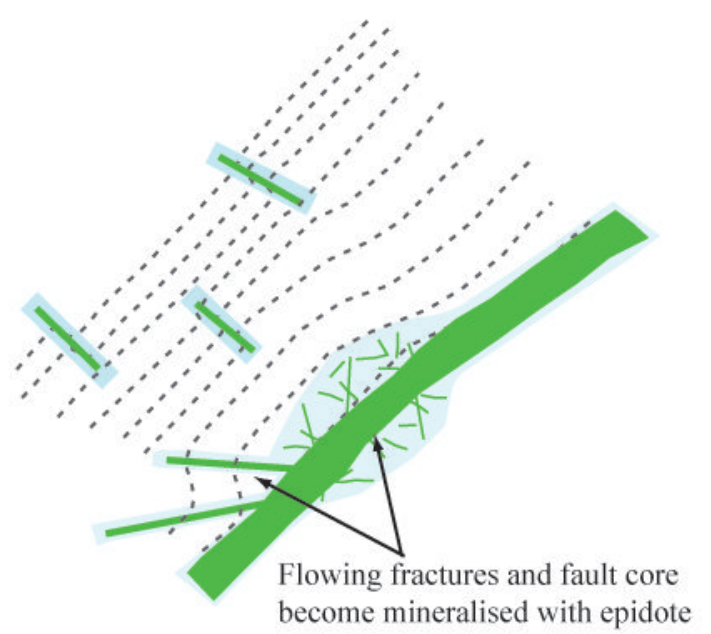

d) Pseudotachylyte cements FC and DZ fractures are annealed, creating a strongly indurated fault zone

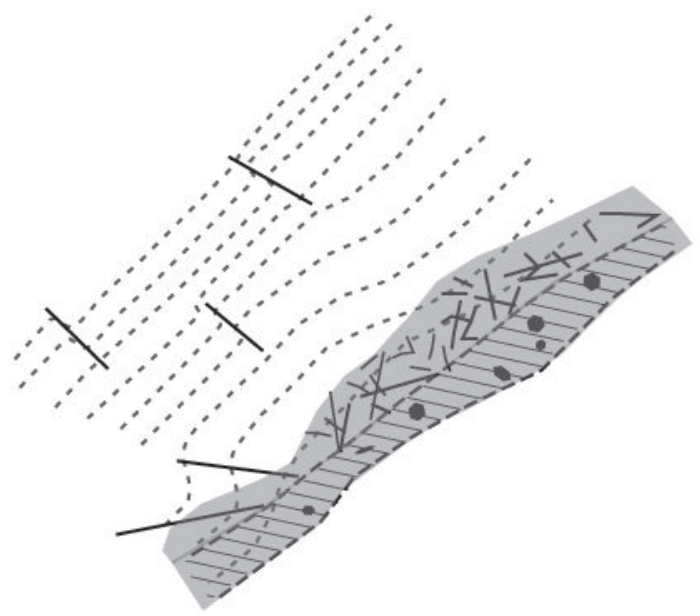


Time (Myrs)

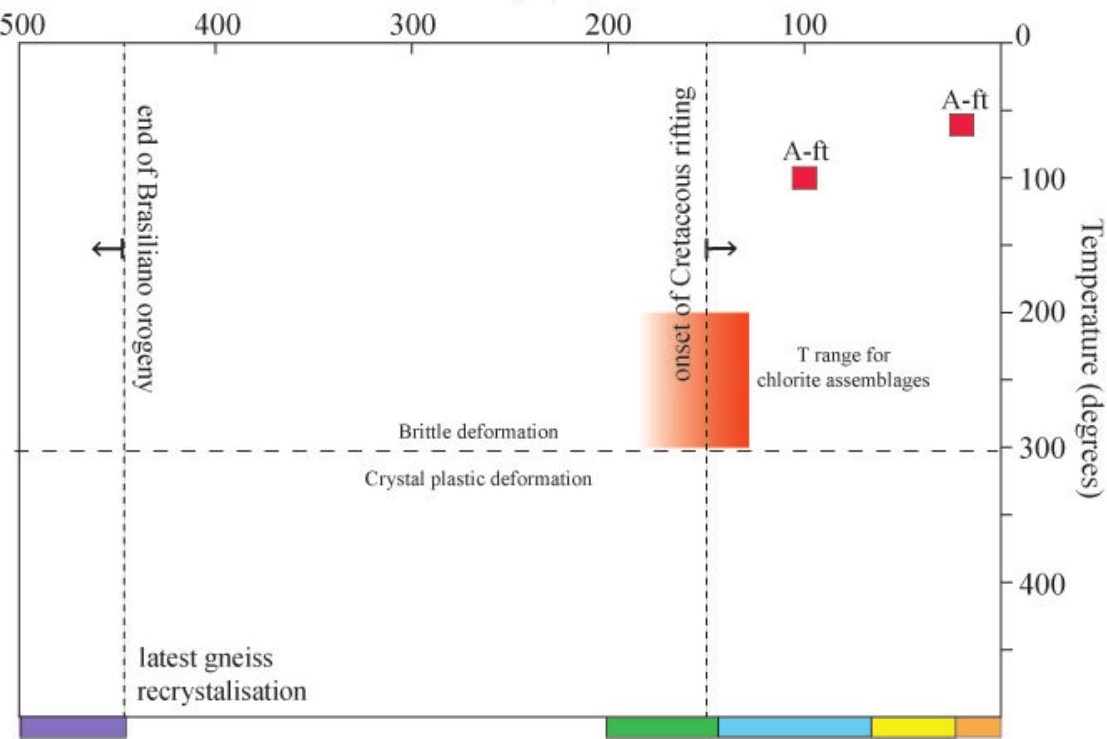

